\title{
An organisational coherence model to maintain employee contributions during organisational crises
}

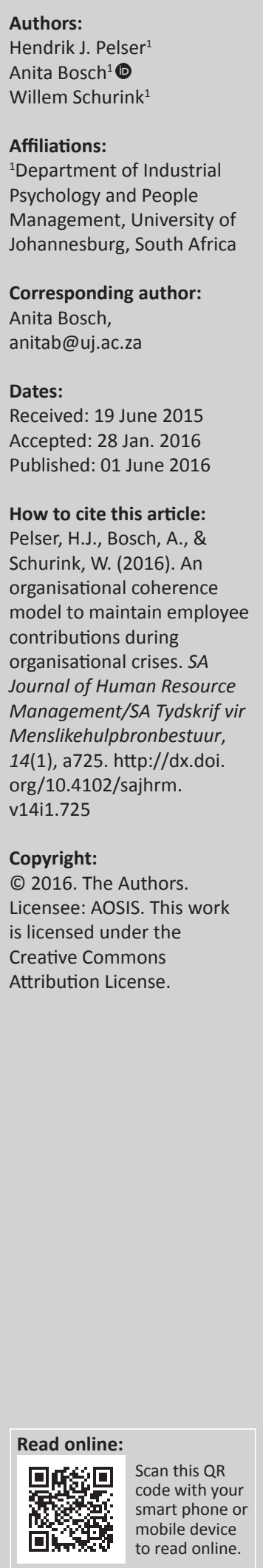

Orientation: Crises that threaten an organisation's continued existence cannot be seen in isolation when considering the perception of threats to individual job security. These threats often go hand in hand with employee panic.

Research purpose: The aim of this study was to establish a model to assist organisations in managing employee emotionality and panic during times of crisis.

Motivation for the study: Environmental crises threaten organisations' existence, threatening employees' livelihood and resulting in employee panic. Panic reduces employees' contributions. Organisations that are successful harness employee contributions at all times.

Research design, approach, and method: A modernist qualitative research methodology was adopted, which included a case study as research strategy, purposive sampling to select 12 research participants, semi-structured interviews for data gathering, focus groups for data verification, and the use of grounded theory for data analysis.

Main findings: An organisation's ability to manage employee panic depends on the relationship between the foundational elements of authentic leadership, crisis readiness, resilience practices, versatile and committed talent, strategic management, quality management, and coherence actions taken during the crisis, which include crisis leadership, ongoing visible communication, mindfulness, work flexibility, and decisions based on the greatest financial need and social support.

Practical/managerial implications: The study provides a best-practice option for managing emotionality during crises for the case organisation and other organisations within the vehicle components and other manufacturing industries.

Contribution/value-add: The Coherence Hexagons Model is presented as a tool to manage employee panic during crisis.

\section{Introduction}

\section{Key focus of the study}

'I couldn't sleep last night but stayed up talking about what was going to happen'. 'It is terrible. Death. It's like a massive earthquake'. A person can be forgiven for thinking that these are lines from a disaster movie. The comments are, in fact, from Lehman Brothers employees Duo Ai and Kirsty McCluskey after the news of the potential collapse of the bank broke (Teather, Orr \& Hopkins, 2008, p. 1). These are also the kind of reactions that may become commonplace in the future as the pressure on organisations increases because of higher levels of competition and environmental volatility. Unmanaged, these reactions could spread panic through organisations, which, in turn, could cause their collapse. Modern managers therefore have a duty to find ways of dealing with emotionality and panic.

\section{Background}

The metaphor of the 'perfect storm' has been proposed to capture the essence of the post-2000 business environment (Dotlich, Cairo \& Rhinesmith, 2009). Contributing to the perfect storm environment is the increase in the scale of crises. The simple truth is that modern crises have no respect for national boundaries (Beck, 1992). The interconnected nature of the modern globalised society exposes a variety of systems to what is termed the transboundary crisis (Boin, 2009). Boin (2009) described a transboundary crisis as one with no clear beginning or end that threatens a range of system elements in the absence of clear-cut plans of action to remedy the consequences.

Note: This article is based on a PhD thesis 'An organisational coherence model to maintain employee contribution during organisational crises' by H.J. Pelser in 2014 at University of Johannesburg, South Africa. 
Organisations and their leaders operate within a crisis-driven context, where discontinuity and unpredictability are the norm. The leadership reality is one that is increasingly complex, diverse, and uncertain. The world has become a place where it is impossible for leadership to keep up with an operating environment that is flat, fast, interdependent, and risky (Dotlich et al., 2009). Crises are, in essence, a business reality, inseparable from day-to-day operations (Elsubbaugh, Fildes \& Rose, 2004).

\section{Purpose}

The motivation for the study was based on the contention that environmental crises will continue to threaten organisations' existence, posing a threat to employees' livelihood resulting in panic. Unmanaged employee emotionality and panic have the potential of putting a marginal business over the edge.

It is in light of these issues that the primary research question was: Which organisational elements contribute to or detract from coherence during perceived organisational crises?

The following supporting sub-questions apply: Which emotions do employees display during perceived crises? Which organisational elements contain or fuel employee emotionality and panic during perceived crises?

\section{Trends gleaned from the literature}

Framed by a set of circumstances where the environment will vacillate between crises, organisations and their leadership have to carve a market niche to serve a customer base that is increasingly informed and less loyal (Alrubaiee \& Al-Nazer, 2010). In order to cope with these potential environmental changes, organisations have embarked upon strategic management. Strategic management is the integration of functions and resources with strategies to maintain alignment with the external environment and ensure future return in competition and stakeholder value (Ehlers \& Lazenby, 2010).

Whereas strategic management's focus is on the offensive aspects of competing in the marketplace, crisis management centres on the defensive capabilities of the company (Penrose, 2000). The aim of crisis management is surviving events threatening an organisation's existence (Mitroff, Diamond \& Murat Alpaslan, 2006), as opposed to the strategic management focus of dealing with opportunities and threats.

The overarching theme of crisis management activities is the use of formal organisational arrangements - systems, structures, and procedures - to secure the continued survival of an organisation during and after a crisis (Elsubbaugh et al., 2004; Massey \& Larsen, 2006; Mitroff et al., 2006). The potential shortfalls of the formalised approach to crisis management is highlighted by the definition of a crisis provided by the London School of Economics' Crisis States Research Centre, which suggests an inability on the part of institutions or organisations to cope with environmental challenges powerful enough to disrupt and even threaten the continued existence of established systems (Porfiriev, 2005).

Threats to established systems that have the potential for creating real panic are those where the logic in the universe is brought into question, because understanding and processes linked to understanding collapse (Weick, 2006). Weick (2006) contended that the elements that hold an organisation together are, in many instances, far more tenuous than managers believe, especially when people are required to fulfil unfamiliar roles in completing ambiguous tasks, in circumstances where key roles are neglected. These kinds of threats have the potential to cause significant psychological suffering (Miller, 2006). This aspect of broader organisational crisis management has largely been neglected in research.

\section{Research design Research approach}

Elliott, Fischer and Rennie (1999) stated that qualitative research aims to understand incidents, encounters, and actions engaged with, and lived through by an individual. The focus of qualitative research is therefore to create an understanding of the phenomenon being investigated, by incorporating the perspectives of the participants (Elliott et al., 1999), that is, elucidating human environments and experiences (Hay, 2005).

A number of factors played a role in opting for a modernist qualitative approach in the present study. These included our need to reflect individual experiences, the ideal of creating accurate theory based on an in-depth literature review, the use of multiple methods and rigorous questioning and analysis, and accounting for a full range of eventualities in a structured manner.

\section{Research strategy}

A case study as research strategy was used. Case studies are, first and foremost, descriptive; secondly, they allow for the generation of rich information about people and particular contexts; and, finally, they create opportunities for the emergence of new ideas and hypotheses (Terre Blanche \& Durrheim, 2002).

The value of using a single exploratory and intrinsic case study lies in its ability to draw attention to pertinent aspects of human behaviour (Schram, 2006). The value of using an intrinsic case study has to be questioned, especially if one considers its limitations in terms of transferability and in creating theory (Stake, 1995). Silverman (2010), however, countered this opinion by providing the following as guidelines to producing explanations that are transferable: firstly, combining qualitative research with quantitative measures of populations; secondly, following a process of purposive sampling, informed by time and funds; thirdly, using theoretical sampling; and finally, using a model to analyse the case, which shows cross-case transferability. 
We followed a single exploratory and intrinsic case study method to examine and describe the reactions of staff to the significant drop in demand for automotive products, with the intention of identifying those organisational realities that impact these reactions.

\section{Research method}

\section{Research setting}

The case organisation was a privately owned engineering firm that provides components and equipment locally and globally to the automotive, construction, and related industries. We refer to the firm as 'David', based on comments from a number of research participants who described the firm as small but tough.

Employees of David live by the motto of 'Our customers come first'. Managers, employees, and teams alike are held accountable for their performance with continuous improvement. They interact on a first-name basis, from the CEO to the sweeper. This, however, does not suggest a lack of respect. Finally, an open-door policy exists at all the management levels.

The year 2011 posed significant challenges to the continued survival of David, which accurately reflects a crisis-driven environment. The specific events that had caused this included the tsunami that hit Japan in March, the floods in Thailand between March and August, air travel over Europe being disrupted by the eruption of Iceland's Grimsvotn volcano in May, strike action locally affecting international freight and transport, snowfalls in August causing the road between Gauteng and Durban to be closed, and global shortages of required raw materials such as nylon. The crises David faced had impacts both individually and collectively on its performance.

\section{Entrée and establishing researcher roles}

We established initial contact with the managing director of David. Formal permission to commence with the research was granted in writing. Acknowledging and accounting for the influence of the researcher, although important, is not sufficient to ensure quality research. In light of this, we treated the information that the research participants offered with an open mind. We also subjected our own preconceptions to ongoing, intense assessments, and we intermittently discussed key research decisions amongst ourselves and a person previously employed by David, which served as peer debriefing exercises (Terre Blanche \& Durrheim, 2002).

\section{Sampling}

Although there is no consensus regarding the correct qualitative sample size, the ideal is to strike a balance between a population not too large to prevent the extraction of thick, rich data, yet large enough to allow 'for data saturation (Flick, 1998; Morse, 1995), theoretical saturation (Strauss \& Corbin, 1990), and informational redundancy
(Lincoln \& Guba, 1985)', originally stated by Sandelowski in Onwuegbuzie and Leech (2007, p. 242). We decided to select employees who potentially had direct and intimate knowledge of the potential ramifications of the recession. Furthermore, we selected employees across all functional areas, and drew participants from the operations and management structural levels. We took special care to include employees who were involved in consultative processes with management.

Whereas the initial sampling we applied was purposive, we thereafter used theoretical sampling, to allow for groups or categories relevant to the research questions, as well as attempts to explain the data (Silverman, 2010). We also used chain-reference sampling to identify new categories of data, until saturation was reached. Here, one identifies critical cases or informants who are well informed, that is, who have a great deal of information about a phenomenon (Cohen \& Crabtree, 2006). We asked the managing director and interviewees to identify individuals who could contribute critically pertinent information.

In light of the above, the research participants indicated in Table 1 were drawn from the three main levels of the organisation's structure.

\section{Data collection methods}

In line with the usage of multiple data collection methods in the modernist tradition, we used interviewing, focus groups, documents, and participant observation.

Face-to-face interviews: Our primary method of data collection was unstructured interviews, utilising an openended question format. Also referred to as in-depth, intensive, focused, or ethnographic interviews, this format allows one to obtain detailed information, clarify reasons for behaviour, and uncover the issues behind interviewees' answers, opinions, feelings, or emotions (Van Rensburg et al., 2009).

We first conducted a pilot interview with one participant. Thereafter, we adjusted the interview guide to ensure that information-rich data could be collected during the interviews. The three main open-ended questions that were posed to the interviewees were:

TABLE 1: Profile of research participants.

\begin{tabular}{llcll}
\hline Gender & Ethnicity & Age group & Tenure & Section \\
\hline Male & Indian & $40-50$ & $10-20$ years & Production \\
Male & Indian & $40-50$ & $10-20$ years & Production \\
Male & Indian & $40-50$ & $10-20$ years & Training \\
Male & Indian & $20-30$ & $0-5$ years & Production \\
Male & Indian & $30-40$ & $5-10$ years & Production \\
Male & Indian & $20-30$ & $5-10$ years & Production \\
Female & Indian & $30-40$ & $5-10$ years & Production \\
Female & Mixed & $40-50$ & $5-10$ years & Production \\
Male & Indian & $20-30$ & $0-5$ years & Production \\
Female & Indian & $40-50$ & $10-20$ years & Production \\
Female & African & $30-40$ & $5-10$ years & Production \\
Male & African & $20-30$ & $5-10$ years & Production \\
\hline
\end{tabular}


1. What do you recall about the period in 2011, between the tsunami hitting Japan and before the floods in Thailand? What was the impact on the organisation and its people?

2. How did the employees respond to this impact? What did the employees do? How did they behave? What emotions did they display?

3. How did management respond to these events? What did the managers do? How did they behave?

Focus group interviews: Focus groups are particularly useful for providing qualitative data. The interaction is considered more natural than interviews, as they reflect the real-life influence that people have on one another (Krueger \& Casey, 2000). We specifically used focus groups, firstly, to confirm our interpretation of the findings from the interviews and, secondly, to construct deeper meaning from the emerging findings. To ensure anonymity, the different levels of employees were kept apart in the focus groups, and we did not share the original interpretations or words used during the interviews.

Additional data sources: A number of additional sources were used, such as process documents detailing issues like tracking and correcting faults, strategies related to cost saving and efficiency, and time sheets. We were also taken on a tour of the facility. We took particular interest in flowcharts indicating the manufacturing processes, the use of buckets to measure waste at the end of shifts, and the large number - comparatively speaking - of female operators on the production line. We also noted other tours being conducted. David's management actively promoted information and knowledge sharing with other manufacturers as part of their own skills development. This data were captured as field notes.

\section{Recording of data}

When recording data, the following are important considerations: the organisation under study, data entry, data backup, and data safety (Bogdan \& Biklen, 2007). All the interviews and focus groups were recorded using two separate digital devices.

Transcribed interviews: Interviews were transcribed. In order to accurately capture the perceptions, emotions, actions, and words of the interviewees and focus group participants, we used field notes to supplement the digital recordings (Hahn, 2008). The field notes and voice recordings were used jointly in finalising the transcripts. We paid specific attention to capturing the full narrative of the recording during the transcription process, making additional annotations to reflect pertinent non-verbal communication such as emotions and facial expressions. Insights recorded during the interviews and focus groups on the written notes were included in the transcripts.

Field notes: Field notes are primarily used to account for the researcher's experiences in collecting and reflecting on data (Bogdan \& Biklen, 2007). We attempted to accurately reflect, through the field notes, from both a descriptive and reflective point of view, the content of both the focus groups and the interviews. We kept these field notes in a transcript file.
A personal log was completed directly after each interview or focus group, in order to assess and refine the data collected during the interviews. We also maintained an analytical log to keep track of any ideas that related to theories encountered in literature (Minichiello, Timewell \& Alexander, 1995).

Data analysis: We selected the process proposed by Merriam (2009) to complete the data analysis, namely category construction, sorting categories and data, naming the categories, and deciding on the number of categories (Merriam, 2009, pp. 178-193).

The process of constructing categories starts with studying the transcripts, field notes, and any other documentation associated with the interviews. The research question acts as the backdrop against which initial observations are noted. The codes aim to highlight data that may have specific value beyond the mere description of the setting within which the data were obtained (Lowe, 1996). Our open coding involved coding by sentence or paragraph, using interview transcripts. We used the open codes as the first step in constructing categories.

Next, we reviewed the transcripts in order to identify common descriptions, and to group these together. This grouping process can be referred to as axial coding. Strauss and Corbin (1990) explained axial coding as the process whereby data are connected in fresh ways, under created categories or subcategories.

We repeated the process described above with all the sets of interview data, with the aim of identifying patterns and regularities, which became the overarching categories and themes within which items were logically grouped (Merriam, 2009 , p. 181). The category itself is an abstraction drawn from the data, and, in essence, takes on a life of its own, separate from the data (Lincoln \& Guba, 1985).

Even though naming the categories is largely an inductive process, the reality is that this is guided by the study's purpose, a researcher's mindset and current knowledge, and the views of the research participants as interpreted by a researcher. We allocated names to the categories that reflected the detail we saw in the data.

We used Merriam's (2009) suggested four guidelines for creating comprehensive and descriptive categories. Firstly, the frequency with which something is raised, that is, the number of times an item is mentioned by research participants, guides the development of a category. Secondly, audiences may indicate the categories they consider to be more credible. Thirdly, some categories may, on the basis of their uniqueness, be retained. Finally, some categories may be unique in their ability to provide unique insights into common problems.

\section{Strategies employed to ensure quality data}

Sharing, interpreting, and representing other people's experiences is, at the same time, a great privilege and a responsibility (Stake, 2010). In order to increase understanding 
of the complex phenomena encountered (Malterud, 2001), we used the four types of triangulation for purposes of credibility, transferability (Lincoln \& Guba, 1985) and dependability (Ryan-Nicholls \& Will, 2009) in the following ways (Pelser, 2014):

- Data triangulation: We used a number of focus groups to verify the information obtained during the interviews.

- Investigator triangulation: We discussed the interview records amongst ourselves, to ensure the accuracy of our interpretation of the data.

- Theory triangulation: We used existing models in the area of crisis- and panic management to deductively assess the accuracy of our interpretations.

- Methodological triangulation: In addition to the information obtained from the interviews and verified via the focus groups, we verified the accuracy of the outcomes with industry experts.

\section{Findings}

The period researched - between the tsunami in Japan in March of 2011 and the floods in Thailand in September 2011 and the objectives of the research, guided the questions of the initial interview guide. The coding process progressed from open coding through axial coding, resulting in 21 categories across the four data sets, as illustrated in Table 2.

We combined the categories through the process of selective coding to create the initial story line. Selective coding is the process through which theory is integrated and created (Strauss \& Corbin, 1998). Developing theory starts with the generation or clarification of a storyline (Pandit, 1996). The analysed storyline becomes the core category of the theory being developed.

We believed that it was apparent from the sheer volume of responses that was grouped into the ongoing communication category that the core category would include a reference to this process. The second element that we believed needed to be linked to the process of ongoing communication was that of transparency. The central category was described as follows: Ongoing visible communication, trust, and transparency are central to managing employee emotionality during organisational crises.

Grounded theory has as its essence the emergence of theory from raw data. Strauss and Corbin (1990), however, considered it appropriate to use those resources that relate to emerging theory as a way of validating the accuracy of findings.

As the basis of grounded theory is the emergence of theory from research, we opted to conduct the review by theme or construct. Mouton (2009) indicated this option as appropriate for both quantitative and qualitative exploratory studies. The central category we developed via the selective coding process, as well as the categories and themes that emerged from the open- and axial coding processes, i.e. the emergent theory, framed the review. From the data, we developed the Organisational Coherence Hexagons Model (Figure 1).

The first column of Table 3 presents a summary of our firstorder constructs, derived empirically; the second column presents the relevant second-order constructs, drawn from literature; and the third column indicates the elements included in the model to account for the first- and secondorder constructs.

\section{Discussion}

The Coherence Hexagons Model identifies the organisational aspects that have to be in place to manage emotionality and maximise employee contribution during times of crisis. These were expanded on in Table 3.

\section{Why hexagons?}

In his writings, Charles Darwin referred to the honeycomb as a masterpiece of engineering, maximising levels of efficiency in terms of labour and wax (Zhang, Duan, Karihaloo \& Wang, 2010). Pappus of Alexandria, the 4th-century geometer, suggested that the value of the hexagon lies in the fact that it holds more honey for the same amount of wax used than any other shape (Zhang et al., 2010). In addition to their levels of efficiency, beehives are, by their very nature, also incredibly robust and resilient.

Modern organisations, as do modern employees, have to be efficient, robust, and resilient to survive the crisis-driven environment. The Coherence Hexagons Model identifies the elements required to promote the development of these characteristics.

In addition to suggesting efficiency, robustness, and resilience, the hexagon shape also allows for each of the major elements to be expanded on through the use of additional interconnecting hexagons. The hexagons could be at the centre or form part of an evolving theory.

\section{Interpreting the hexagons}

Several elements have to be embedded in an organisation to provide the foundation for managing emotionality and maximising contributions during times of crisis. These elements, although represented as different sides of the

TABLE 2: Data categories.

\begin{tabular}{lclccc}
\hline Data set & Questions & Representing & Open coding themes & Axial coding themes & Categories constructed \\
\hline 1 & $1 \& 2$ & Impact of crisis event & 41 & 10 \\
2 & $2 / 2$ & Employee actions during crisis & 13 & 4 \\
3 & $3 \& 4$ & Management actions during crisis & 50 & 3 & 12 \\
4 & $5,6 \& 7$ & $\begin{array}{l}\text { Organisational elements that contributed to } \\
\text { effective crisis management actions }\end{array}$ & 48 & 4 \\
\hline
\end{tabular}


TABLE 3: Elements of the Coherence Hexagons Model.

First-order constructs
Two universally consistent human needs can be identified: physical survival and
autonomy (Doyal \& Gough, 1991).

Versatile, committed talent

The knock-on effects of unemployment or loss of income include fewer resources for food, education, and health (Barrientos \& Hulme, 2008; Fildis, 2011).

Job loss is associated with trauma and stress, which not only impact the individual, but also the quality of the relationships with his or her spouse and children (McKee-Ryan, 2006). Concerns about loss of income Poorer people have fewer or inadequate buffers to protect them from long-term job loss (Fildis, 2011). In general, South Afric

Rumours

Rumours are carried through the so-called 'grapevine' (Robbins, Judge, Odendaal \& Roodt, 2009). The greater the thematic importance of the rumour is, the greater the level of rumour mongering will be (Allport \& Postman, 1947; Rosnow, 1991). Managers need to monitor the grapevine to control the spread of rumours (Archer, 1992; Robbins et al., 2009).

Impact on productivity

Organisational consequences of crises include: a negative impact on the business climate and culture (Miller, 2006), paralysis (Jun \& Myung, 2001; Roux-Dufort, 2009),

and financial setbacks (Kim, 2010; Miller, 2006). (Cole, 2010; Grobler et al., 2011; Robbins et al., 2009).

Financial need of individua The impact of a loss of income on female workers appears to be more significant and employees may be as a result of gender inequalities through perceived income generation roles of men and women in society (Fildis, 2011; Holdsworth, 2011).

of men and women in society (Fildis, 2011; Holdsworth, 2011). identity, belonging, self-worth, and self-esteem (Clapham, 2005; Holdsworth, 2011; Mallett, 2004; Massachusetts Coalition for the Homeless vs. Dukakis, 1986).

Availability of information The Internet is to be considered both a threat and an ally in crisis management (Gonza'lez-Herrero \& Smith, 2008).

When attempts are made to find information on a crisis, employees are naturally inclined to turn to networks and contacts with which they are familiar. These include social media such as Facebook and Twitter (Dynes, 1994; Gahran, 2008; Jennex, 2013; Meier, 2013).

Seeking alternatives In order to resolve crises effectively, organisational teams are required to mobilise additional resources (staff, money, and advice), which are often not at the disposal of the organisation (Choi, Sung \& Kim, 2010).

Employees' survival strategies during crises are aimed at allowing them to continue working, including finding alternative means of income, walking to work to save costs, and borrowing money from family and friends (Chagonda, 2012; Hungwe, 2011).

Spirituality or religiousness $\quad$ People experiencing stress turn to religion (Carver \& Scheier, 1999; Gall \& Grant, 2005; McRae \& Costa, 2006; Samson \& Zerter, 2003).

People spontaneously turn to prayer to cope with problems (Barnes, Powell-Griner \& Nahin, 2004; McCaffrey, Eisenberg, Legedza, Davis \& Phillips, 2004; cited in Lambert, Fincham \& Graham, 2011; Pargament, Ano \& Wachholtz, 2005). Emotional resilience can be linked to spirituality and religiousness (Greeff \& Loubser, 2008; Hadzic, 2011; Moreira-Almeida, Neto \& Koeig, 2006; Walsh, 2003).

2008; Hadzic, 2011; Moreira-Almeida, Neto \& Koeig, 2006; Walsh, 2003). There is a clear

Ongoing communication

Establishing and training a multi-departmental crisis management team. A crisis communication plan to lend legitimacy to crisis responses (Massey \& Larsen, 2006; Seeger, 2006).

Actions taken must conform to the expectations of society (Alpaslan, Green \& Mitroff, 2009).

Commitment to seeking Elements that are substitutable during times of crisis (Hellriegel et al., 2007)

Versatile, committed talent Work flexibility

Ongoing, visible communication

Quality management Mindfulness

\section{Financial need}

Ongoing, visible communication

\section{Versatile committed talent} Work flexibility

Social support

alternatives

Emotional quotient (Cole, 2010; Echterling et al., 2005; Feldman \& Kuyken, 2011; Goleman, Boyatzis \& McKee, 2002).

Empathy Stakeholders expect accountability and transparency in crisis responses (Florini, 2007;
Goleman et al., 2002; Grobler et al., 2011; Padgett, Cheng \& Parekh, 2013; Silver, 2005;

Transparency Goleman et al., 2002; Grobler et
Ulmer, Sellnow \& Seeger, 2007).

Crisis mindset

Modern organisations are considered open systems operating at the edge of chaos (Echterling et al., 2005).

Living with risk is a defining reality of modern times (Hinchcliffe \& Woodward, 2004).

The role of leadership is to prepare an organisation for the unexpected (Jennings, The role of leadership is
Castro \& Smith, 2005).

Leaders have to anticipate and display an awareness of unexpected events (Weick \& Sutcliffe, 2001).

Individual or organisational Employees who feel that they belong to the organisation tend to cope better during times of crisis (Felicia \& loana, 2012).

times of crisis (Felicia \& loana, 2012). Employees who believe they have greater control over their lives at work can, in a sen
protect their own interests and reduce the risk of opportunistic action on the part of management (Singh, 2009; Whitener \& Brodt, 1998).

The process of talent management goes hand in hand with giving employees greater control over their lives at work (Grobler et al., 2011). Organisational incentive plans aim to link a proportion of employee compensation to the performance of teams and, ultimately, to the entire organisation (Grobler et al., 2011).

Continuous improvement The process of continuous improvement is an essential strategy to counter the Chinese strategy of cost innovation (Dotlich et al., 2009). Continuous improvement is the ongoing process of frequent, small, and evolutionary enhancements made to organisational practices, processes, products, and services (Cole, 2010).

Three interrelated variables form the cornerstone of an innovative organisation: structure, culture, and human resources (Dotlich et al., 2009).

\section{Ongoing, visible communication}

Authentic leadership Strategic management Crisis leadership

Authentic leadership Social support

Authentic leadership Resilience practices

Crisis readiness

Versatile, committed talent

Quality management 
TABLE 3 (Continues...): Elements of the Coherence Hexagons Model.

\begin{tabular}{|c|c|c|}
\hline First-order constructs & Second-order constructs & $\begin{array}{l}\text { Model elements to accommodate or } \\
\text { address construct }\end{array}$ \\
\hline Industry awareness & $\begin{array}{l}\text { Identify the industry within which an organisation competes (Ehlers \& Lazenby, 2010). } \\
\text { Understand the characteristics that make the industry unique. Identify competitors in } \\
\text { an industry (David, 2011). } \\
\text { Identify the industry's key success factors (David, 2011). }\end{array}$ & Quality management \\
\hline Diversification & $\begin{array}{l}\text { Diversification is a sound option, only if the business can add real shareholder value } \\
\text { through consistently high returns on investment, using synergies created by operating } \\
\text { across different industries (David, 2011). }\end{array}$ & Crisis readiness \\
\hline Multi-skilled, learning workforce & $\begin{array}{l}\text { The transition from the concept of employment (having a job) to that of employability } \\
\text { (Forrier \& Sels, 2003; Fugate, Kinicki \& Blake, 2004). } \\
\text { Characteristics that are essential for successful modern employee are the speed, depth, } \\
\text { and breadth of their learning (Grobler et al., 2011). } \\
\text { Versatilists are individuals who learn deeply and widely. Because of their learning, they } \\
\text { are able to transition seamlessly across organisational boundaries (Friedman, 2005). }\end{array}$ & Versatile, committed talent \\
\hline Leadership and trust & $\begin{array}{l}\text { A decrease in management ethics and an increase in macro-environmental threats have } \\
\text { necessitated authentic (positive) leadership (Cooper, Scandura \& Schriesheim, 2005). } \\
\text { The four components of authentic leadership are 'self-awareness, balanced processing, } \\
\text { self-regulation, and relational transparency' (Zamahani, Ghorbani \& Rezaei, 2011, p. 659). } \\
\text { Dealing with a crisis is the responsibility of leadership. (Felicia \& loana, 2012). } \\
\text { Employees turn to leaders for assurance, clarity, and guidance when facing uncertainty, } \\
\text { threats, and crises (Goleman et al., 2002). } \\
\text { Crisis leaders play a significant role in setting the appropriate tone during the crisis } \\
\text { (Seeger, Sellow \& Ulmer, 2003). } \\
\text { Effective crisis management requires collective leadership. } \\
\text { Psychological flexibility is a key characteristic of a crisis leader (Hayes, Strosahl \& Wilson, } \\
\text { 1999; Moran, 2011). } \\
\text { Mindfulness is the ability to remain aware of the realities of a situation, and to isolate } \\
\text { those environmental stimuli that are important in determining an appropriate response, } \\
\text { and then persisting in the attainment of selected objectives (Moran, 2011). } \\
\text { Resonate leadership has as its cornerstones the domains of 'emotional intelligence: } \\
\text { self-awareness, self-management, social awareness, and relationship management' } \\
\text { (Goleman et al., 2002, p. 30). }\end{array}$ & $\begin{array}{l}\text { Authentic leadership } \\
\text { Resilience practices }\end{array}$ \\
\hline Organisational resilience & $\begin{array}{l}\text { Speed, transparency, and accountability are elements essential for organisational } \\
\text { resilience. }\end{array}$ & Resilience practices \\
\hline Culture, wellness and compensation & $\begin{array}{l}\text { Workplace programmes to treat mental health symptoms, such as counselling and } \\
\text { therapy, show a significant return on investment (Hilton, Scuffham, Vecchio \& } \\
\text { Whiteford, 2010). } \\
\text { Essential elements of effective support during crises are: providing social support, } \\
\text { creating opportunities for attachment, displaying empathy, establishing rapport, } \\
\text { providing counselling and psychotherapy, and linking employees with a helper } \\
\text { (Echterling et al., 2005). } \\
\text { Social support during times of crisis is essential. } \\
\text { Pauchant and Mitroff (1988) identified positive self-regard corporations (PSRCs) as } \\
\text { ideally suited to coping with crises. A PSRC considers itself in relation to the larger } \\
\text { external environment; includes both its primary and secondary stakeholders in crisis } \\
\text { management actions; views customers as an end in themselves, that is, as fellow } \\
\text { humans with a range of needs; acknowledges crises and engage in a series of actions to } \\
\text { counteract the threats the crisis poses as part of an integrated crisis management } \\
\text { process; is acutely aware of its strengths and specific competencies, as well as its } \\
\text { weaknesses and deficiencies; accepts that guilt and anxiety are natural responses to a } \\
\text { crisis; embraces the paradoxes of competition and co-operation, as well as of } \\
\text { individualism and collectivism; and its culture provides the framework within which } \\
\text { employees learn and grow (Pauchant \& Mitroff, 1988). }\end{array}$ & $\begin{array}{l}\text { Versatile committed talent Strategic } \\
\text { management Social support }\end{array}$ \\
\hline
\end{tabular}

hexagon, are interrelated. Leaders are therefore expected to ensure that these sides remain congruent with each other. The sides opposite each other indicate elements that feed into, and off of, each other.

\section{The coherence hexagons' foundational elements and sub-elements}

Authentic leadership makes up the first side, and, because of its importance, is placed at the top of the hexagon. Modern employees expect to have leaders who they can trust, who maintain high levels of ethics, and who are emotionally intelligent. The presence of these qualities will ensure that employees respond positively during times of crisis when leaders deploy specific crisis-related actions.

Crisis readiness makes up the second side of the hexagon. Leaders who adopt a mindset of 'anything can happen' are in a better position to remain calm during crises. Calm leaders are essential to ensure calm employees. Crisis planning as the second sub-element of crisis readiness anticipates possible contingencies and provides plans of action to deal with these. These plans promote the perception of leaders being in control.
Resilience practices make up the third side of the hexagon. Organisations with a positive track record of effectively coping with, and rebounding from, previous crises have stories to share of 'how we have done this before'. These stories serve as a reminder to employees of the potential of the organisation to bounce back. Sharing these stories forms an essential part of managing emotionality. Resilience practices are underpinned by the sub-elements of speed, transparency, and accountability. Speed refers to issues that relate to, amongst others, the turnaround time to recover from previous crises. Transparency refers to the extent to which stakeholders are able to understand the internal workings of the organisation. Accountability refers to the extent to which leaders accept responsibility for their own actions.

Situated opposite to authentic leadership is versatile, committed talent. Along with authentic leadership, versatile committed talent represents the human element of the model. The sub-elements corporate social responsibility, wellness, talent management, lifelong or wide learning, and multiskilling - each contributes to the presence of versatilists in the organisation. Versatile employees appreciate 


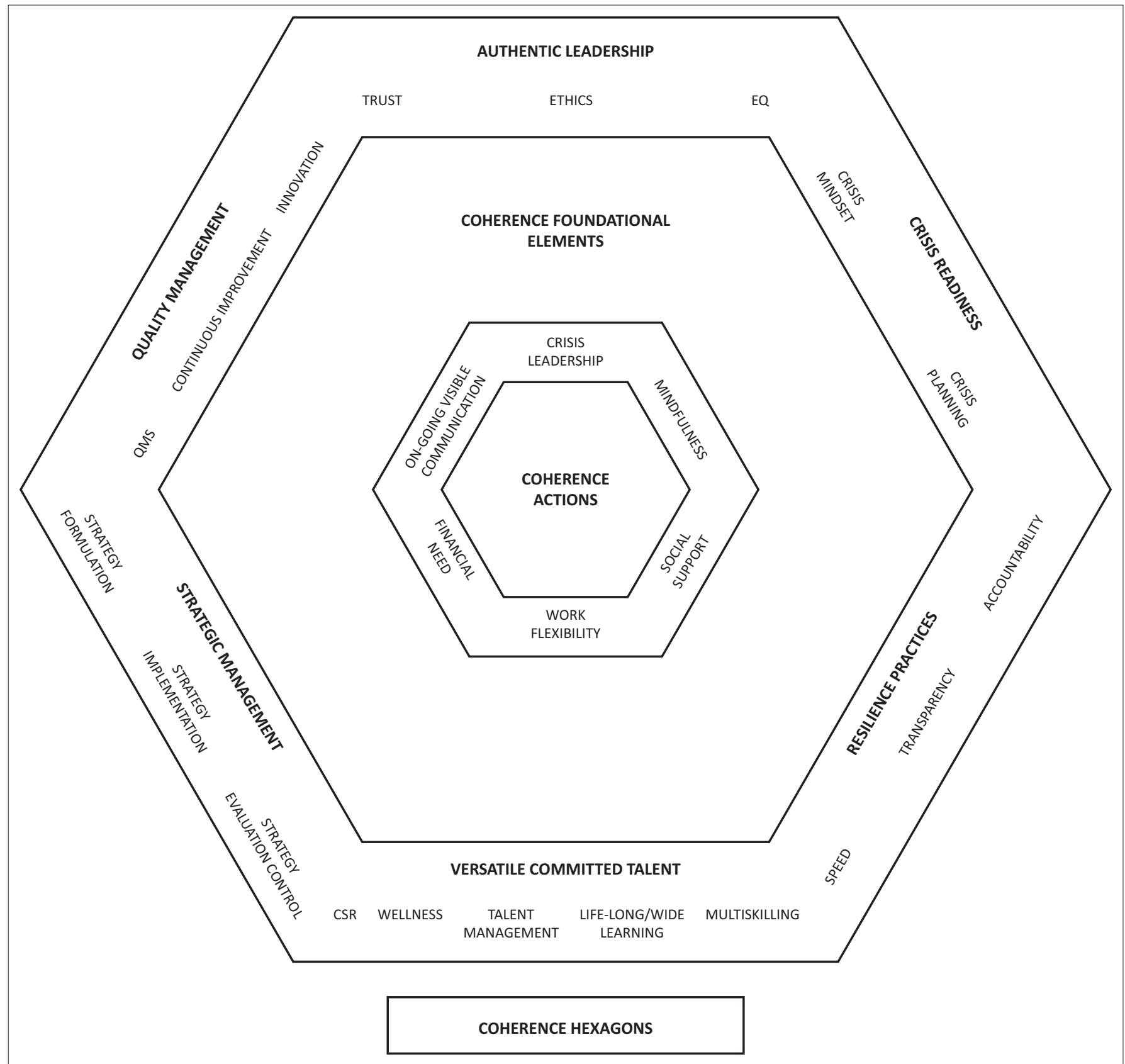

Source: Pelser, H. (2014). An organisational coherence model to maintain employee contribution during organisational crises (p. 174). Unpublished doctoral thesis, University of Johannesburg, South Africa

FIGURE 1: The Coherence Hexagons Model.

the importance of employability, as opposed to employment. Versatilists also panic less during crises.

Strategic management and crisis readiness make up the planning component of the model. Strategy formulation, as the first phase of the strategic management process, provides a number of essential factors to guide behaviour during crises, such as the organisation's vision, mission, and value statements, along with strategies to counteract the impact of crisis events. Developing and creating an appropriate culture and structure to, if necessary, frame crisis management activities form part of the strategy implementation phase. Finally, strategic evaluation and control is essential to verify whether the strategic plan has unfolded as intended, and if necessary to initiate corrective action.
Quality management and resilience practices combine to form the systems element of the model. Quality management and its sub-elements of a quality management system, continuous improvement, and innovation contribute to an organisation's competitive advantage. During times of crisis, these subelements are used to focus employees who are distracted because of stress and emotionality.

\section{The coherence hexagons' action elements}

The success of the coherence actions undertaken as per the central split hexagon depends on the quality of the foundational processes of the coherence hexagons. The elements are split into those that relate to the behaviour of crisis leaders and those that specifically accommodate the needs of employees. 
Crisis leadership, as the top of the central hexagon and linked to authentic leadership, relates to those actions undertaken by those in authority to maintain employee contribution. Successful crisis leaders are calm and visible, and take charge of situations as they occur.

Intimately linked with crisis leadership is the need for those in positions of authority to engage in ongoing visible communication. Leaders are expected to remain up to date with events as they unfold, deal with rumours as they spread, and to truthfully communicate actions taken to deal with the crisis as it evolves.

Mindfulness is a practice that allows leaders and followers to focus on the immediate, despite the large number of emotional and other distractions that may compete for attention during times of crisis.

Intimately linked with the presence of versatile committed talent is the need for organisations to be flexible to accommodate and capitalise on these employees and their competencies. Work flexibility refers to the opportunities available to employees to move between sections in the organisation and/or to move to other organisations to make up for income lost as a result of actions like short time or layoffs. This aspect plays a key role in retaining talent in the long run.

Organisational crises, especially those with an economic basis, are often associated with actions such as short time and layoffs. Organisations can manage employee panic by basing their staffing decisions on the principle of greatest financial need. Employees who fall into the category of greatest financial need are often single parents or from single-income families.

Finally, people need to feel that they have someone in their corner during times of crisis. Social support can come in many forms, including prayer groups, counselling or therapy, and team members supporting each other. Organisations have to make these opportunities available during times of crisis.

\section{Limitations of the study}

Firstly, one of the potential drawbacks related to the selection of the research participants for the present study is that we drew people from different levels in the organisation's structure, that is, manager, group leader, team leader, and operator. Even though we did not observe anything in particular in this regard, the use of people who report to each other may have constrained the research participants in fully contributing during the interviews.

Secondly, a lack of generalisability is often considered the greatest drawback of using a single case study (Bryman \& Bell, 2007). Even though some writers argue that the process of theoretical sampling should create a theory that is exportable (as opposed to generalisable) to situations where circumstances similar to the case exist (Flyvbjerg, 2006; Morse, 1999a; Popay, Rogers \& Williams, 1998; Yin, 2003), we believe we have to acknowledge the limitations imposed by using a single research setting.

Thirdly, Merriam (2009) identified the selective use of data by the researcher and potential researcher bias because of researcher subjectivity as another limitation inherent in qualitative research. Even though we believe that, through the use of reflexive practices, peer reviews, member checks, peer debriefing, audit trails, and rich, thick descriptions, we may have addressed this issue, we acknowledge this as a potential limitation.

Fourthly, grounded theory is not immune to criticism. The most common criticism is a lack of scientific (deductive) analysis (Gasson, 2004) and its inability to render testable theory (Goldthorpe, 2000).

The final limitation relates to the actual outcome of the crisis period used to frame the study. The opportunities presented by the subsequent flooding in Thailand ensured a positive outcome. No jobs were lost, and additional overtime made up for loss of income. It would be naive not to think that the research participants' experiences may have been different, had the outcome been negative, that is retrenchments, et cetera.

\section{Recommendations}

Additional research needs to be conducted on the areas depicted on the external sides of the hexagon. The research should focus on identifying the support elements required in the areas of authentic leadership, crisis readiness, resilience practices, strategic management, and quality management. The research should be based within the context of the crisisdriven environment.

Another area of research could be the implementation of the Coherence Hexagons Model, specifically ways to diagnose an organisation's existing design and the processes to transform the organisation to meet the requirements of the model.

Finally, a study should be undertaken to identify those elements that signal coherence, that is, the point at which employee emotionality and panic have been addressed. At this stage, managers can refocus their leadership on addressing ongoing strategic and operational issues.

\section{Conclusion}

The world is changing at a rapid pace and turmoil is becoming the norm. The management of employee panic in times of crises is fast becoming one of the competitive advantages of any business. The Coherence Hexagon Model presented in this paper provides a practical way of addressing coherence when all else may seem out of control. 


\section{Acknowledgements Competing interests}

The authors declare that they have no financial or personal relationships which may have inappropriately influenced them in writing this article.

\section{Authors' contributions}

H.J.P. was the PhD student, A.B. was the supervisor, and W.S. was the co-supervisor of the study which this article is based upon.

\section{References}

Allport, G., \& Postman, L. (1947). The psychology of rumour. New York: Henry Holt and Company.

Alpaslan, C., Green, S., \& Mitroff, I. (2009). Corporate governance in the context of crises: Towards a stakeholder theory of crisis management. Journal of Contingencies and Crisis Management, 17(1), 38-49. http://dx.doi.org/10.1111/ j.1468-5973.2009.00555.x

Alrubaiee, L., \& Al-Nazer, N. (2010). Investigate the impact of relationship marketing orientation on customer loyalty: The customer's perspective. International Journal of Marketing Studies, I/(1), 155-174. http://dx.doi.org/10.5539/ijms.v2n1p155

Archer, J. (1992). Campus in crisis: Coping with fear and panic related to serial murders. Journal of Counselling and Development, 71(1), 96-100. http://dx.doi. org/10.1002/j.1556-6676.1992.tb02181

Barnes, P., Powell-Griner, E.M., \& Nahin, R. (2004). Complementary and alternative medicine use among adults: United States, 2002. CDC. Atlanta, GA: Advance Data From Vital and Health Statistics. Retrieved 24 March 2010, from http://nccam.nih. gov/news/camsurvey.htm

Barrientos, A., \& Hulme, D. (2008). Social protection for the poor and poorest: An introduction. In A. Barrientos, \& D. Hulme (Eds.), Social protection for the poor and the poorest: Concepts, policies and politics, (pp. 3-24). Basingstoke, UK: Palgrave-Macmillan.

Beck, U. (1992). Risk society: Towards a new modernity. Thousand Oaks, CA: Sage Publications.

Bogdan, R., \& Biklen, S. (2007). Qualitative research for education: An introduction to theory and methods (5th edn.). Boston, MA: Pearson Education.

Boin, A. (2009). The new world of crises and crisis management: Implications for policymaking and research. Review of Policy Research, 26(4), 367-377. http://dx.doi.org/10.1111/j.1541-1338.2009.00389.x

Bryman, A., \& Bell, E. (2007). Business research methods (2nd edn.). Oxford, NY: Oxford University Press.

Carver, C., \& Scheier, M. (1999). Stress, coping, and self-regulatory processes. In L. Pervin \& O. John (Eds.), Handbook of personality: Theory and research (pp. 553-575). New York: Guilford Press.

Chagonda, T. (2012). Teachers' and bank workers' responses to Zimbabwe's crisis: Uneven effects, different strategies. Journal of Contemporary African Studies, 30(1), 83-97. http://dx.doi.org/10.1080/02589001.2012.639656

Choi, J., Sung, S., \& Kim, M. (2010). How do groups react to unexpected threats? Crisis management in organisational teams. Social Behaviour and Personality, 38(6), 805-828. http://dx.doi.org/10.2224/sbp.2010.38.6.805

Clapham, D. (2005). The meaning of housing: A pathways approach. Bristol: Policy Press. http://dx.doi.org/10.1111/j.1467-9906.2007.00325_2.x

Cohen, D., \& Crabtree, B. (2006). Snowball or chain sampling. Qualitative Research Guidelines Project. Retrieved September 12, 2010, from http://www.qualres.org/ HomeSnow-3816.html

Cole, K. (2010). Management: Theory and practice (4th edn.). French Forest, NSW, Australia: Pearson.

Cooper, C., Scandura, T., \& Schriesheim, C. (2005). Looking forward but learning from our past: Potential challenges to developing authentic leadership theory and authentic leaders. The Leadership Quarterly, 16(3), 475-493. http://dx.doi.org/ 10.1016/j.leaqua.2005.03.008

David, F. (2011). Strategic management: Concepts and cases (13th edn.). NJ, Uppe Saddle River: Prentice Hall.

Dotlich, D.L., Cairo, P.C., \& Rhinesmith, S.H. (2009). Leading in times of crisis: Navigating through complexity, diversity, and uncertainty to save your business. San Francisco, CA: Josey-Bass.

Doyal, L., \& Gough, I. (1991). A theory of human need. Basingstoke, UK: Macmillan.

Dynes, R. (1994). Community emergency planning: False assumptions and inappropriate analogies. International Journal of Mass Emergencies and Disasters, 12(2), 141-158.

Echterling, L., Presbury, J., \& Edson Mckee, J. (2005). Crisis intervention: Promoting resilience and resolution in troubled times. Upper Saddle River, NJ: Pearson Merrill Prentice Hall.

Ehlers, M., \& Lazenby, J. (2010). Strategic management: South African concepts and cases (3rd edn.). Pretoria, South Africa: Van Schaik.
Elliott, R., Fischer, C., \& Rennie, D. (1999). The British Psychological Society evolving guidelines for publication of qualitative research studies in psychology and related fields. British Journal of Clinical Psychology, 38, 215-229.

Elsubbaugh, S., Fildes, R., \& Rose, M. (2004). Preparation for crisis management: A proposed model and empirical evidence. Journal of Contingencies and Crisis Management, 12(3), 112-127. http://dx.doi.org/10.1111/j.0966-0879.2004.00441.x

Feldman, C., \& Kuyken, W. (2011). Compassion in the lanscape of suffering. Contemporary Buddhism, 12(1), 143-155. http://dx.doi.org/10.1080/14639947.2 011.564831

Felicia, S., \& loana, F. (2012). Leadership and crisis management during crisis situations. Constanta Maritime University Annals, 17(1), 303-306. Retrieved 05 May 2013, from http://cmu-edu.eu/RePEc/cmc/annals/303-v17.pdf

Fildis, A. (2011). The welfare of women and children during the global economic crisis. Trakya Üniversitesi Sosyal Bilimler Dergisi, 13(2), 297-308.

Flick, U. (1998). An introduction to qualitative research. London, United Kingdom: Sage Publications.

Florini, A. (2007). The battle over transparency. In A. Florini \& A. Florini (Ed.), The right to know: Transparency for an open world (pp. 1-18). New York, NY: Columbia University Press.

Flyvbjerg, B. (2006). Five misunderstandings about case-study research. Qualitative Inquiry, 12(2), 219-245. http://dx.doi.org/10.1177/1077800405284363

Forrier, A., \& Sels, L. (2003). The concept of employability: A complex mosaic International Journal of Human Resource Development and Management, 3(2), 102-124. http://dx.doi.org/10.1504/IJHRDM.2003.002414

Friedman, T. (2005). The world is flat: A brief history of the twenty-first century. New York, NY: Farrar, Straus, and Giroux.

Fugate, M., Kinicki, A., \& Blake, E. (2004). Employability: A psycho-social construct, its dimensions and applications. Journal of Vocational Behaviour, 65(1), 14-38. http://dx.doi.org/10.1016/j.jvb.2003.10.005

Gahran, A. (2008, November 26). Following Mumbai attacks via social media. Contentious.Com. Retrieved 23 March 2010, from http://www.contentious.com/ Contentious.Com. Retrieved 23 March 2010, from http://
2008/11/26/following-mumbai-attacks-via-social-media/

Gall, T. \& Grant, K. (2005). Spiritual disposition and understanding illness. Pastora Psychology, 53(6), 515-533. http://dx.doi.org/10.1007/s11089-005-4818-y

Gasson, S. (2004). Rigor in grounded theory research: An interpretive perspective on generating theory from qualitative field studies. In M. Whitman \& A. Woszczynski (Eds.), The handbook of information systems research (pp. 79-102). Hershey, PA: IGI Global. http://dx.doi.org/10.4018/978-1-59140-144-5

Goldthorpe, J. (2000). On sociology: Numbers, narratives, and the integration of research and theory. Oxford: Oxford University Press.

Goleman, D., Boyatzis, R., \& McKee, A. (2002). The new leaders: Transforming the art of leadership into the science of results. London, UK: Time Warner Books.

Gonza'lez-Herrero, A., \& Smith, S. (2008). Management on the web: How Internetbased technologies are changing the way public relations professionals handle business crises. Journal of Contingencies and Crisis Management, 16(3), 143-153. $\mathrm{http}: / / \mathrm{dx}$.doi.org/10.1111/j.1468-5973.2008.00543.x

Greeff, A., \& Loubser, K. (2008). Spirituality as a resiliency quality in Xhosa-speaking families in South Africa. Journal of Religion and Health, 47(3), 288-301. http://dx.doi. families in South Africa. Journal of
org/10.1007/s10943-007-9157-7

Grobler, P., Bothma, R., Brewster, C., Carey, L., Holland, P., \& Wärnich, S. (2011) Contemporary issues in human resources management (4th edn.). Cape Town, South Africa: Oxford Press.

Hadzic, M. (2011). Spirituality and health: Current research and future directions. Journal of Spirituality in Mental Health, 13(4), 223-235. http://dx.doi.org/10.1080/ 19349637.2011.616080

Hahn, C. (2008). Doing qualitative research using your computer: A practical guide. London, United Kingdom: Sage Publications.

Hay, I. (2005). Qualitative research methods in human geography (2nd edn.). Oxford: Oxford University Press.

Hayes, S., Strosahl, K., \& Wilson, K. (1999). Acceptance and commitment therapy: An experiential approach to behaviour change. New York: Guilford Press.

Hellriegel, D., Jackson, S., Slocum, J., Staude, G., Amos, T., Oosthuizen, T., et al. (2007) Management: Second South African edition. Cape Town, South Africa: Oxford University Press.

Hilton, M., Scuffham, P., Vecchio, N., \& Whiteford, H. (2010). Productivity, using the interaction of mental health symptoms and treatment status to estimate lost employee productivity. Australian and New Zealand Journal of Psychiatry, 44(2), employee productivity. Australian and New Zealand Journ

Hinchcliffe, S., \& Woodward, K. (2004). The natural and the social: Uncertainty, risk, change. New York: Routledge.

Holdsworth, L. (2011). Sole voices: Experiences of non-home-owning sole mother renters. Journal of Family Studies, 17(1), 59-70. http://dx.doi.org/10.5172/jfs.2011.17.1.59

Hungwe, C. (2011). A review of the challenges and survival strategies of university workers during the economic crisis: A case study of the Midlands State University (MSU) workers in Zimbabwe. International Journal Of Psychological Studies, 3(2) 249-265. http://dx.doi.org/10.5539/ijps.v3n2p249

Jennex, M. (2013). Is social media effective in a crisis situation? San Diego University. Retrieved 03 October 2013, from http://cbaweb.sdsu.edu/news/stories/2013/07/ Social_Media

Jennings, C., Castro, N., \& Smith, C. (2005). Model for assessing adaptive effectiveness development. Journal of Contingencies and Crisis Management, 13(3), 129-134. http://dx.doi.org/10.1111/j.1468-5973.2005.00467.x 
Jun, J.S., \& Myung, S.P. (2001). Crisis and organisational paralysis: The lingering problem of Korean public administration. Journal of Contingencies and Crisis Management, 9(1), 3-13. http://dx.doi.org/10.1111/1468-5973.00148

Kim, S. (2010). Timeline: Toyota's rise and run-up to its recall crisis. Reuters. Retrieved 12 May 2013, from http://www.reuters.com/article/2010/02/09/ toyota-idUSN0920267420100209

Krueger, R., \& Casey, M. (2000). Focus groups: A practical guide for applied research (3rd edn.). Thousand Oaks, CA: Sage Publications.

Lambert, N.M., Fincham, F.D., \& Graham, S.M. (2011). Understanding the layperson's perception of prayer: A prototype analysis of prayer. Psychology of Religion and Spirituality, 3(1), 55-56. http://dx.doi.org/10.1037/a0021596

Lincoln, Y., \& Guba, E. (1985). Naturalistic enquiry. Beverly Hills, CA: Sage Publications.

Lowe, A. (1996). An explanation of grounded theory. Swedish School of Economics and Business Administration - Working Papers, 336, 1-18.

Mallett, S. (2004). Understanding home: A critical review of literature. The Sociological Review, 52(1), 62-84. http://dx.doi.org/10.1111/j.1467-954X.2004.00442.x

Malterud, K. (2001). Qualitative research: Standards, challenges, and guidelines. The Lancet, 358(9280), 483-488. http://dx.doi.org/10.1016/s0140-6736(08)61345-8

Massachusetts Coalition for the Homeless vs. Dukakis, Civil No. 80109 (Suffolk Superior Court May 5, 1986).

Massey, J.E., \& Larsen, J.P. (2006). Crisis management in real time: How to successfully plan for and respond to a crisis. Journal or Promotion Management, 12(3-4), 6397. http://dx.doi.org/10.1300/J057v12n03_06

McCaffrey, A., Eisenberg, D., Legedza, A., Davis, R., \& Phillips, R. (2004). Prayer for health concerns: Results of a national survey on prevalence and patterns of use. Archives of Internal Medicine, 164(8), 858-862. http://dx.doi.org/10.1001/ archinte.164.8.858

McKee-Ryan, F. (2006). Job loss. In J. Greenhaus \& G. Callanan (Eds.), Encyclopedia of career development (pp. 428-434). Thousand Oaks, CA: Sage Publications. http://dx.doi.org/10.4135/9781412952675.n149

McRae, R., \& Costa, P. (2006). Personality, coping, and coping effectiveness in an adult sample. Journal of Personality, 54, 385-405. http://dx.doi.org/10.1111/j.1467-6494. 1986.tb00401.x

Meier, P. (2013, February 14). Did terrorists use Twitter to increase situational awareness? iRevolution. Retrieved 05 May 2013, from http://irevolution.net/ 2013/02/14/terrorists-used-twitter/

Merriam, S. (2009). Qualitative research: A guide to design and implementation. San Francisco, CA: John Wiley \& Sons.

Miller, D. (2006). Organisational pathology and industrial crisis. In D. Smith, \& D. Elliot (Eds.), Key readings in crisis management: Systems and structures for prevention and recovery (pp. 75-83). New York: Routledge.

Minichiello, V.A., Timewell, E., \& Alexander, L. (1995). In-depth interviewing (2nd edn.). Melbourne, Australia: Longman.

Mitroff, I., Diamond, M., \& Murat Alpaslan, C. (2006). How prepared are America's colleges and universities for major crises. Change, 38(1), 61-67. http://dx.doi. org/10.3200/CHNG.38.1.61-67

Moran, D. (2011). ACT for leadership: Using acceptance and commitment training to develop crisis-resilient change managers. International Journal of Behavioural Consultation and Therapy, 6(4), 341-355.

Moreira-Almeida, A., Neto, F., \& Koeig, H. (2006). Religiousness and mental health A review. Revista Brazileria de Psiquiatria, 28(3), 242-250. http://dx.doi.org/ 10.1590/S1516-44462006005000006

Morse, J. (1995). The significance of saturation. Qualitative Health Research, 5(2), 147-149. http://dx.doi.org/10.1177/104973239500500201

Morse, J. (1999a). Qualitative generalizability. Qualitative Health Research, 9(1), 5-6.

Mouton, J. (2009). How to succeed in your master's and doctoral studies: A South African guide and resource book. Pretoria, South Africa: Van Schaik.

Onwuegbuzie, A., \& Leech, N. (2007). Sampling designs in qualitative research: Making the sampling process more public. The Qualitative Report, 12(2), 238-254. Retrieved 12 February 2010, from http://www.nova.edu/ssss/QR/QR12-2/ onwuegbuzie1.pdf

Padgett, D., Cheng, S., \& Parekh, V. (2013). The quest for transparency and accountability: Communicating responsibly to stakeholders in crises. Asian Socia Science, 9(9), 31-44. http://dx.doi.org/10.5539/ass.v9n9p31

Pandit, N. (1996). The creation of theory: A recent application of grounded theory method. Nova Education. Retrieved 12 February 2010, from http://www.nova. edu/ssss/QR/QR2-4/pandit.html

Pargament, K., Ano, G., \& Wachholtz, A. (2005). The religious dimension of coping: Advances in theory, research and practice. In R. Paloutzian \& E. Park (Eds.), Handbook of the psychology of religion and spirituality (pp. 479-495). New York: Guilford Press.

Pasquali, V., Aridas, T., Bedell, D., \& Magno, A. (2012). Household savings rates. Global Finance. Retrieved 13 June 2013, from http://www.gfmag.com/tools/globaldatabase/economic-data/12065-household-saving-rates.html\#axzz2fnkOoSpR

Pauchant, T., \& Mitroff, I. (1988). Crisis prone versus crisis avoiding organisations: Is your company's culture its own worst enemy in creating crises? Organisation Environment, 2(1), 53-63. http://dx.doi.org/10.1177/108602668800200105

Pelser, H. (2014). An organisational coherence model to maintain employee contribution during organisational crises. Unpublished doctoral thesis, University of Johannesburg, South Africa.
Penrose, J. (2000). The role of perception in crisis planning. Public Relations Review, 26(2), 155-171. http://dx.doi.org/10.1016/S0363-8111(00)00038-2

Popay, J., Rogers, A., \& Williams, G. (1998). Rationale and standards for the systematic review of qualitative literature in health. Services Research. Qualitative Health Research, 8(3), 341-351. http://dx.doi.org/10.1177/104973239800800305

Porfiriev, B. (2005). Managing crises in the EU: Some reflections of a non-EU scholar. Journal of Contingencies and Crisis Management, 13(4), 145-152. http://dx.doi. org/10.1111/j.1468-5973.2005.00470.x

Robbins, S., Judge, T., Odendaal, A., \& Roodt, G. (2009). Organisational behaviour Global and Southern African perspectives (2nd edn.). Cape Town, South Africa: Pearson Education.

Rosnow, R. (1991). Inside rumour: A personal journey. American Psychologist, 46(5), 484-496. http://dx.doi.org/10.1037/0003-066X.46.5.484

Roux-Dufort, C. (2009). The devil lies in details! How crises build up within organisations. Journal of Contingencies and Crisis Management, 17(1), 4-11. http://dx.doi.org/10.1111/j.1468-5973.2009.00563.x

Ryan-Nicholls, K., \& Will, C. (2009). Rigour in qualitative research: Mechanisms for control. Nurse Researcher, 16(3), 70-84. http://dx.doi.org/10.7748/ nr2009.04.16.3.70.c6947

Samson, A., \& Zerter, B. (2003). The experience of spirituality in the psycho-social adaptation of cancer survivors. Journal of Pastoral Care and Counselling, 57(3), 329-343.

SASI. (2013). Latest statistics: Selected economic indicators for South Africa. The South African Savings Institute. Retrieved 23 June 2013, from http://www. savingsinstitute. co.za/

Schram, T. (2006). Conceptualizing and proposing qualitative research (2nd edn.). Upper Saddle River, NJ: Pearson Prentice.

Seeger, M. (2006). Best practices in crisis communication: An expert panel process Journal of Applied Communication Research, 34(3), 232-244. http://dx.doi.org/ 10.1080/00909880600769944

Seeger, M., Sellow, T., \& Ulmer, R. (2003). Communication and organisational crisis. Westport, CT: Praeger.

Silver, D. (2005). Creating transparency for public companies: The convergence of PR and IR in the Post-Sarbanes-Oxley Marketplace. The Public Relations Strategist, 11, 14-17.

Silverman, D. (2010). Doing qualitative research (3rd edn.). London, United Kingdom: Sage Publications.

Singh, S. (2009). A study on employee participation in decision making. Unitar E-Journal, 5(1), 20-38. Retrieved 12 June 2010, from http://www.teo-education. com/teophotos/albums/userpics/A\%20Study $\% 20$ on $\% 20$ Employee $\% 20$ Participation\%20in\%20Decision\%20Making-1.pdf

Stake, R. (1995). The art of case study research. Thousand Oaks, CA: Sage Publications.

Stake, R. (2010). Qualitative research: Studying how things work. New York: The Guilford Press.

Strauss, A., \& Corbin, J. (1990). Basics of qualitative research: Grounded theory procedures and techniques (2nd edn.). London, United Kingdom: Sage Publications.

Strauss, A., \& Corbin, J. (1998). Basics of qualitative research: Techniques and procedures for developing grounded theory (2nd edn.). Thousand Oaks, CA: Sage Publications.

Teather, D., Orr, J., \& Hopkins, K. (2008, September 15). Wall Street crisis: Lehman staff tell their stories. The Guardian. Retrieved 13 June 2013, from http://www. theguardian.com/business/2008/sep/15/lehmanbrothers.creditcrunch1

Terre Blanche, M., \& Durrheim, D. (2002). Research in practice: Applied methods for the social sciences. Cape Town, South Africa: UCT Press.

Ulmer, R., Sellnow, T., \& Seeger, M. (2007). Effective crisis communication: Moving from crisis to opportunity. Thousand Oaks, CA: Sage Publications. http://dx.doi. org/10.1080/15205430701528663

Van Rensburg, G.H., Alpaslan, A.H., Du Plooy, G.M., Gelderblom, D., Van Eeden, R., \& Wigston, D.J. (2009). Research in the social sciences. Pretoria: UNISA.

Walsh, F. (2003). Family resilience: Strenghts forged through adversity. In F. Walsh (Ed.), Normal family processes (pp. 399-421). New York: The Guilford Press.

Weick, K. (2006). The colllapse of sensemaking in organisations: The Mann Gulch disaster. In D. Smith \& D. Elliot (Eds.), Key readings in crisis management: Systems and structures for prevention and recovery (pp. 258-283). New York: Routledge.

Weick, K., \& Sutcliffe, K. (2001). Managing the unexpected: Assuring high performance in an age of uncertainty. San Francisco, CA: Jossey-Bass.

Whitener, E., \& Brodt, S. (1998). Managers as initiators of trust: An exchange relationship framework for understanding managerial trustworthy behaviour. Academy of Management Review, 23(3), 513-530. http://dx.doi.org/10.5465/ AMR.1998.926624

Yin, R. (2003). Case study research: Design and methods (3rd edn.). Thousand Oaks, CA: Sage Publications.

Zamahani, M., Ghorbani, V., \& Rezaei, F. (2011). Impact of authentic leadership and psychological capital on followers' trust and performance. Australian Journal of Basic and Applied Sciences, 5(12), 658-667.

Zhang, K., Duan, H., Karihaloo, B., \& Wang, J. (2010). Hierarchical, multi-layered cell walls reinforced by recycled silk cocoons enhance the structural integrity of honeybee combs. Proceedings of the National Academy of Sciences of the United States of America (PNAS), 107(21), 9502-9506. http://dx.doi.org/ 10.1073\%2Fpnas.0912066107 